\title{
Mechanism of Lignin Degradation via White Rot Fungi Explored Using Spectral Analysis and Gas Chromatography-Mass Spectrometry
}

\author{
Libo Jin, ${ }^{\mathrm{a}}$ Guoming Zeng, ${ }^{\text {,c }}$ Haojie Chen, ${ }^{\mathrm{a}}$ Lei Wang, ${ }^{\mathrm{a}}$ Hao Ji, ${ }^{\mathrm{a}}$ Sue Lin, ${ }^{\mathrm{a}}$ Renyi Peng, \\ and Da Sun ${ }^{\mathrm{a}, \mathrm{d}, *}$
}

\begin{abstract}
The mechanism of lignin degradation via white rot fungi was studied. Phanerochaete chrysosporium and Pleurotus ostreatus were used for all the experiments, i.e., measuring the concentration and structure of alkali lignins and studying the effect of the substrate concentration and enzyme activity on the removal. Gas chromatography-mass spectrometry was performed on the reaction liquid of the lignin degradation enzyme system. Alkali lignin had a characteristic absorption spectrum with a peak at approximately $280 \mathrm{~nm}$. Precipitation in the laccase (Lac) degradation system occurred earlier, as well as being more obvious than that in the manganese peroxidase (Mnp) degradation system. The maximum removal was $29.4 \%$ in the Mnp degradation system at a concentration of $40 \mathrm{mg} / \mathrm{L}$. The removal increased in a concentration-dependent manner in the Lac degradation system. The increase in Mnp and Lac enzyme activity led to an increased alkali lignin removal. The removal of the control group was significantly lower than the experimental degradation systems. The degradation mainly produced organic acids, esters, and aromatic substances. In conclusion, white rot fungi could effectively remove alkali lignin, in which precipitation played a major role, followed by enzymolysis; the enzymolysis was associated with the alkali lignin concentration and enzyme activity.
\end{abstract}

Keywords: Lignin; White rot fungi; Degradation; Manganese peroxidase; Laccase

Contact information: a: Institute of Life Sciences, Wenzhou University, Wenzhou 325025 China; b: Chongqing University of Science and Technology, Chongqing 401331 China; c: China Metallurgical Construction Engineering Group Co., Ltd, Chongqing 643000 China; d: Biomedical Collaborative Innovation Center of Zhejiang Province \& Engineering Laboratory of Zhejiang Province for Pharmaceutical Development of Growth Factors, Biomedical Collaborative Innovation Center of Wenzhou, Wenzhou 325035 China; Libo Jin and Guoming Zeng contributed equally to this work;

*Corresponding author: sunday@wzu.edu.cn

\section{INTRODUCTION}

Lignins belong to a class of high-molecular organic compounds with natural reserves second only to cellulose, but it is difficult to degrade them. The molecular structure of lignin contains a large number of benzene ring structures, and it is a relatively complex aromatic polymer (Wang et al. 2010; Cheng and Brewer 2017). As a type of natural resource associated with cellulose and a large storage capacity, the degradation, recovery, and reuse of lignins have attracted a large amount of attention (Tian et al. 2015; Jose et al. 2017). At present, except for a portion of the recycled lignins that are directly used in construction, water treatment, and fertilizer, there is still a large amount of lignins that results in environmental pollution. Therefore, the effective degradation of lignins 
remains an urgent issue for the papermaking and pulping industry (Soloman et al. 2009).

Currently, there are multiple methods to degrade lignin, which include the hydrogenation reduction method, the catalytic oxidation method, the electrochemical method, the ultrasonic method, the microwave method, the microbial method, etc. Among them, the microbial method can completely mineralize lignins and therefore has received great attention from researchers (Yoshikata et al. 2014). As a kind of filamentous fungi, white rot fungi can cause white wood rot and degrade aromatic pollutants, primarily through the use of lignin peroxidase (Lip), manganese peroxidase (Mnp), and laccase (Lac) (Ryu et al. 2003). The enzymes Mnp and Lac play a major role in degradation and are directly involved in the degradation of dyes. Manganese peroxidase is an extracellular heme protein with a carbonyl group, which requires a $\mathrm{H}_{2} \mathrm{O}_{2}$ catalysis and the participation of $\mathrm{Mn}^{+}$. During the growth of mycelium, Mnp is secreted, and due to the catalysis of the enzyme, the benzene ring in the lignin structure undergoes a single electron oxidation reaction to form a phenoxy radical. Subsequently, a series of non-enzymatically catalyzed free radical reactions are followed by degradation, including the removal of the methoxy groups, the cleavage of the $\mathrm{C} \alpha-\mathrm{C} \beta$ and alkylaryl ether bonds on the side chains, and the cleavage of the benzene rings (Hofrichter et al. 2001; Ghiaci et al. 2010). The degradation products of lignins are absorbed by the mycelium and further oxidized into $\mathrm{CO}_{2}$ and $\mathrm{H}_{2} \mathrm{O}$. Laccase is a copper-containing oxidase, and copper plays a crucial role in degradation. As a polyphenol oxidase, it can deprotonate hydroxyl groups to form phenoloxy anions in the presence of molecular oxygen, leading to the breakage of the side chains of lignin-type structural units, including $\mathrm{CC}$ bonds, methoxy, and dihydroxyl, in which copper plays a decisive role (Ihssen et al. 2017). Lignin degradation via Lac does not involve $\mathrm{H}_{2} \mathrm{O}_{2}$ (Saparrat et al. 2008).

Phanerochaete chrysosporium strains are traditional model strains, which are typical Lip- and Mnp-producing strains, and generally they cannot secrete Lac (De Koker et al. 1998). A previous study by Ye et al. (2010) has shown that the selective production of Mnp could be controlled through controlling the level of $\mathrm{Mn}^{2+}$ ions in the culture. Thus, Mnp can be selectively obtained via the fermentation of Phanerochaete chrysosporium strains. Pleurotus ostreatus strains have become a model strain for degrading pollutants, due to its superior degradation performance. Pleurotus ostreatus can secrete both Lac and Mnp, but it has a particularly high Lac yield (Pezzella et al. 2008). Therefore, in this study, Lac was obtained via the fermentation and culture of Pleurotus ostreatus.

Various studies have reported the degradation of lignins via enzymes from white rot fungi, but little is known about the mechanism. The authors constructed different degradation systems, and GC-MS was performed on the reaction liquid of the lignin degradation enzyme systems to explore the underlying mechanism.

\section{EXPERIMENTAL}

\section{Fungal Strains and Bamboo Powder}

Phanerochaete chrysosporium (obtained from the China Industrial Microbial Species Preservation and Management Center) was cultured on solid PDA medium at 35 ${ }^{\circ} \mathrm{C}$ for $5 \mathrm{~d}$ to obtain medium full of spores. Pleurotus ostreatus strain (obtained from the Chongqing Agricultural Science Research Center) was cultured on solid PDA medium at $30{ }^{\circ} \mathrm{C}$ for $12 \mathrm{~d}$ to obtain medium full of mycelium. Neosinocalamus affinis (Chongqing, China) was cut into small pieces $(1 \mathrm{~cm}$ to $3 \mathrm{~cm}$ ) with a chopper, and then those pieces were

Zeng et al. (2021). "Lignin white rot fungal degradation," BioResources 16(3), 5494-5507. 5495 
crushed into bamboo powder with the FY-130 disintegrator (Taisite Instruments Ltd., Tianjin, China).

\section{Lignin Extraction}

The bamboo powder passing through the 200 -mesh screen was mixed with a $15 \%$ $\mathrm{NaOH}$ solution at a dry mass ratio of 1 to 1 and cooked at $140{ }^{\circ} \mathrm{C}$ for $2 \mathrm{~h}$. After this, the black liquor was transferred to a RE-2000A rotary evaporator (Shanghai Jiapeng Technology Co., Ltd, Shanghai, China) and dried under a vacuum at $90{ }^{\circ} \mathrm{C}$ to obtain crude lignins, which were dissolved in $140 \mathrm{~mL}$ of pyridine, acetic acid, and water (in a ratio of 9 to 1 to 4$)$. The solution was extracted with chloroform $(160 \mathrm{~mL})$ and deionized water (20 $\mathrm{mL}$ ), which caused it to separate into layers. After that, the lignins were precipitated in ether after the lower organic layer was extracted 3 times to concentrate it, and then dried in a vacuum.

\section{Ultraviolet Spectral Analysis}

The purified lignins were dissolved in a $0.1 \mathrm{~mol} / \mathrm{L} \mathrm{NaOH}$ solution to obtain a $1 \mathrm{~g} / \mathrm{L}$ original alkali lignin solution. An acetic acid-sodium acetate buffer (with a pH of 5.0) was added to both the original and the degradation reaction lignin solutions. Then, the solution was scanned at wavelengths ranging from 200 to $800 \mathrm{~nm}$ using a Lambda $900 \mathrm{UV}-1100$ spectrophotometer (Perkin Elmer, Waltham, MA). The alkali lignin solution was mixed with the acetic acid-sodium acetate buffer (with a pH of 5.0) to obtain the 10, 20, 40, 60, 80 , and $100 \mathrm{mg} / \mathrm{L}$ solutions. Then, the standard curve was made by measuring the absorbance value at the characteristic absorption peak in the ultraviolet spectrophotometer.

\section{Fourier Transform Infrared (FTIR) Spectroscopic Analysis}

The purified alkali lignins (1 mg) and $\mathrm{KBr}$ were mixed and ground to form the samples. A Fourier infrared spectrometer (VERTEX70, Bruker, Billerica, MA) with a resolution of $4 \mathrm{~cm}^{-1}$ ), in the range of $4000 \mathrm{~cm}^{-1}$ to $400 \mathrm{~cm}^{-1}$, was used to analyze the structure of the lignins (10 scans were performed).

\section{Construction of the Degradation Systems with Different Lignin Concentrations}

After $10 \mathrm{~d}$ of fermentation, the broths of two white rot strains were centrifuged at $4000 \mathrm{rpm}$ for $20 \mathrm{~min}$. The supernatant was used to prepare the degradation system (with a $\mathrm{pH}$ of 5.0) of the Mnp and Lac enzymes, with an alkali lignin concentration of 10, 20, 40, 60,80 , and $100 \mathrm{mg} / \mathrm{L}$, respectively. The enzyme activity was $2.4 \mathrm{U} / \mathrm{mL}$ and the amount of $\mathrm{Mn}^{2+}$ was $0.04 \mathrm{mmol} / \mathrm{L}$. Then, $0.04 \mathrm{mmol} / \mathrm{L}$ of $\mathrm{H}_{2} \mathrm{O}_{2}$ was added to the system to initiate the reaction for $24 \mathrm{~h}$ at $40{ }^{\circ} \mathrm{C}$ with 3 replicates for each group. A protein inactivation degradation system under the same conditions was included as the control group.

\section{Construction of the Degradation Systems with Different Enzyme Activities}

The enzyme activity of the two different white rot strain broths after $10 \mathrm{~d}$ of fermentation was determined. The fermentation broths with enzyme activities of 0.8, 2.4, 4.0, 5.6, and 7.2 U/mL were prepared using the fermentation broth with inactivated proteins. Then, the fermentation broth was prepared to enzyme activity levels of $0.4,1.2$, 2.0, 2.8, and $3.6 \mathrm{U} / \mathrm{mL}$, with an alkali lignin concentration of $10 \mathrm{mg} / \mathrm{L}$. The degradation system ran for $24 \mathrm{~h}$ at $40{ }^{\circ} \mathrm{C}$ with 3 replicates for each group. 


\section{Gas-Chromatography Mass Spectroscopy (GC-MS) Analysis}

The GC-MS analysis was performed as previously described by Jordaan and Laurens (2015). Samples from the degradation system were collected after running the reaction for $24 \mathrm{~h}$, and the samples were analyzed via GC-MS. The degradation liquid (15 $\mathrm{mL}$ ) was centrifuged at $10000 \mathrm{rpm}$ for $10 \mathrm{~min}$, and the supernatant was removed via $\mathrm{n}$ hexane extraction $(25 \mathrm{~mL})$, which was performed three times. The organic phase was combined, $\mathrm{Na}_{2} \mathrm{SO}_{4}$ was added, and the sample was dehydrated, followed by placing it into the rotary evaporator. Then, $0.5 \mathrm{~mL}$ of N,O-bis (trimethy-1-silyl) trifluoroacetamide (Sigma-Aldrich, St. Louis, MO) was silanized at $50{ }^{\circ} \mathrm{C}$ for $30 \mathrm{~min}$ after vacuum concentration to $1 \mathrm{~mL}$ at $70{ }^{\circ} \mathrm{C}$. The excess silanizing reagent was expelled with nitrogen as the test sample.

\section{Statistical Analysis}

Analysis of variance (ANOVA) was performed on the data obtained from the FTIR spectrometer using the Design Expert software (version 6, StatEase Inc., Minneapolis, $\mathrm{MN})$.

\section{RESULTS AND DISCUSSION}

\section{Changes in Alkali Lignin Concentration}

To investigate the alkali lignin concentrations, ultraviolet spectral analysis was performed to measure the optical density (OD), and a standard curve was drawn. The results showed that the alkali lignins had a characteristic absorption spectrum with a peak at approximately $280 \mathrm{~nm}$ (Fig. 1A), suggesting that the removal of alkali lignins could be calculated by measuring the change in the absorbance value at a wavelength of $280 \mathrm{~nm}$ after the sample is collected from degradation system. The standard curve was drawn at $280 \mathrm{~nm}$, and the OD trace value was linearly related to the alkali lignin concentration (the correlation coefficient was 0.9991 (Fig. 1B)). The linear regression equation is $y=0.015 x$ + 0.0135 (Baldrian and Šnajdr 2006).
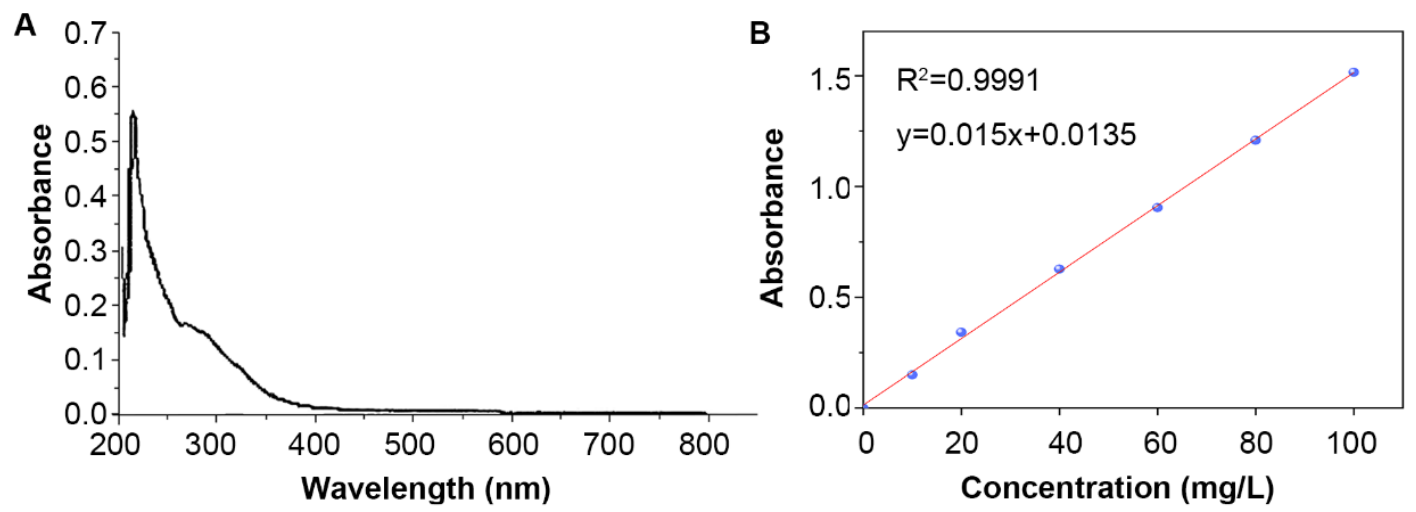

Fig. 1. Changes in the alkali lignin concentration $(A)$ the ultraviolet spectrogram of the alkali lignin at a $200 \mathrm{~nm}$ to $800 \mathrm{~nm}$ wavelength; and (B) the standard curve of alkali lignin

\section{Structure of Alkali Lignin}

To explore the structure of alkali lignins, a FTIR spectrometer was used to measure the wavenumber of the alkali lignins. The FTIR spectrometer results showed that alkali 
lignins have an aromatic ring skeleton and multiple functional groups, e.g., phydroxyphenyl, guaiacol, and lilac core, indicating that the bamboo lignin is a GSH-type (Table 1 and Fig. 2). Furthermore, the structure of the purified lignin contains a large number of benzene structures, which is a complex aromatic compound.

Table 1. Alkali Lignin Wavenumber Determined via FTIR

\begin{tabular}{|c|c|c|}
\hline No. & Description & Wavenumber $\mathbf{( c m}^{-1}$ ) \\
\hline 1 & Stretching vibration of the hydroxyl group & 3407.9 \\
\hline 2 & Stretching vibration of $\mathrm{C}-\mathrm{H}$ & 2847.7 to 3001.9 \\
\hline 3 & Stretching vibration of the aromatic ring skeleton & 1509.0 to 1597.0 \\
\hline 4 & Deformation vibration of $-\mathrm{CH}_{3}$ - and $-\mathrm{CH}_{2}$ & 1463.2 \\
\hline 5 & Aromatic ring skeleton $-\mathrm{CH}$ - stretching vibration & 1423.2 \\
\hline 6 & Stretching vibration of Ar-OH & 1384.3 \\
\hline 7 & The lilacs nuclear & 1329.4 \\
\hline 8 & Stretching vibration of the guaiacyl cyclidium $\mathrm{C}=\mathrm{O}$ & 1272.0 \\
\hline 9 & Stretching vibration of the lilac aromatic ring $\mathrm{C}-\mathrm{H}$ & 1222.0 \\
\hline 10 & Stretching vibration of the ester linkage C-O-C & 1122.8 \\
\hline 11 & Bending vibration in the C-H plane of the aromatic ring & 1032.2 \\
\hline 12 & Bending vibration of the aromatic ring C-H surface & 915.9 \\
\hline 13 & $\begin{array}{c}\text { Bending vibration of the aromatic ring C-H surface, lilac } \\
\text { ring 2,6, on - hydroxyphenyl ring anywhere }\end{array}$ & 834.9 \\
\hline 14 & Deformation vibration of the aromatic ring $\mathrm{C}-\mathrm{H}$ & 603.4 to 669.5 \\
\hline
\end{tabular}

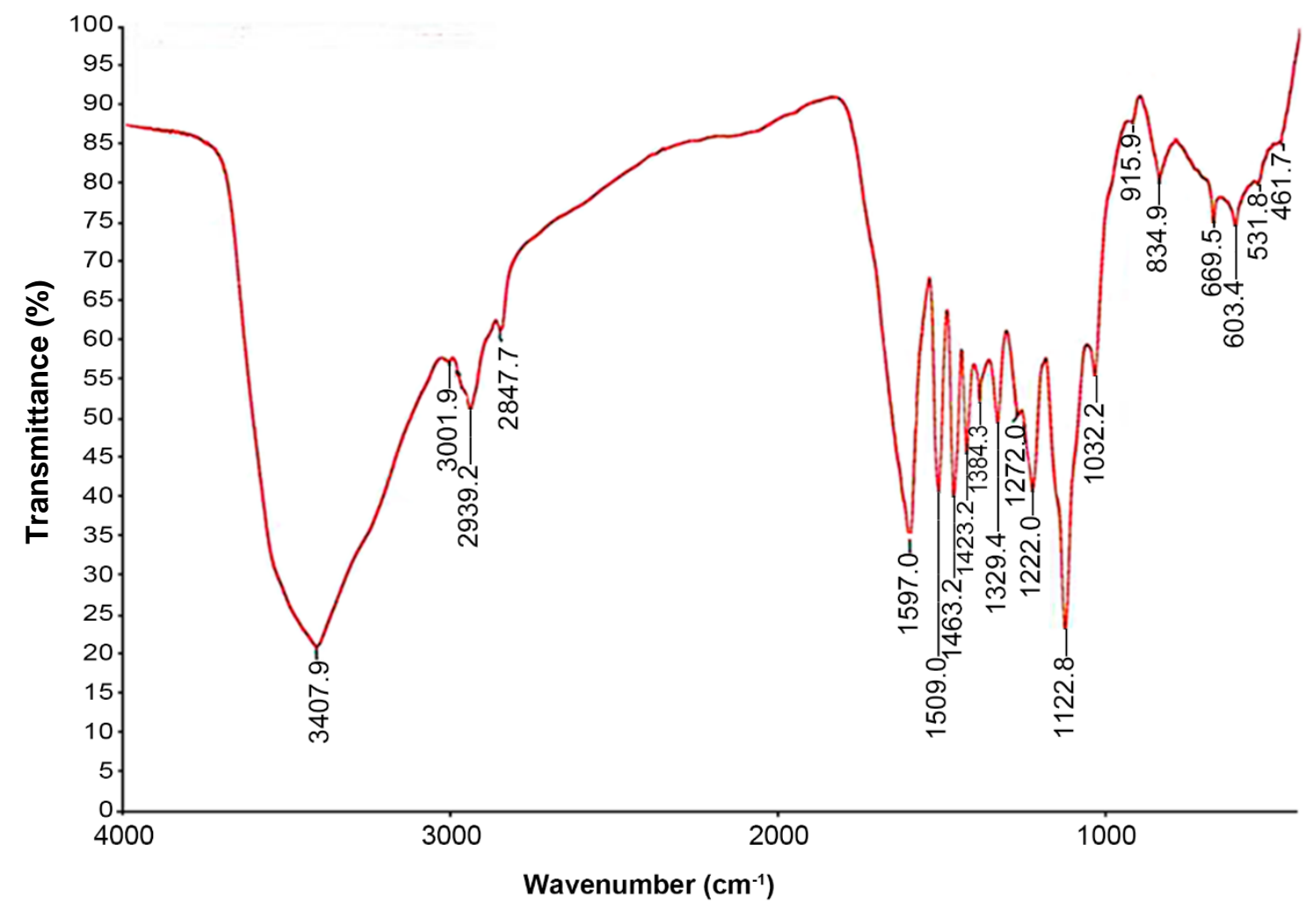

Fig. 2. The structure of an alkali lignin detected via FTIR spectroscopy 


\section{The Effect of the Substrate Concentration on the Degradation of Alkali Lignins via Manganese Peroxidase and Laccase}

To investigate the relation between the substrate concentration and the removal, a degradation system with different lignin concentrations was constructed. The results revealed that flocculent precipitation occurred in the degradation system during the reaction, especially when the alkali lignin concentration was greater than $20 \mathrm{mg} / \mathrm{L}$, which led to a large amount of flocculent precipitation being observed after $6 \mathrm{~h}$. Flocculation in the Lac degradation system occurred earlier, as well as being more obvious than the flocculation in the Mnp degradation system. For the Mnp degradation system, the maximum removal was $29.4 \%$ at a concentration of $40 \mathrm{mg} / \mathrm{L}$, which decreased as the concentration of alkali lignin increased (decreased to $13.5 \%$ at a concentration of 100 $\mathrm{mg} / \mathrm{L}$ ). For the Lac degradation system, the removal of alkali lignins was up-regulated in a concentration-dependent manner. It reached up to $62.7 \%$ at a concentration of $100 \mathrm{mg} / \mathrm{L}$ (Fig. 3). The results found that alkali lignins were removed by the Lac degradation system at a higher alkali lignin removal.

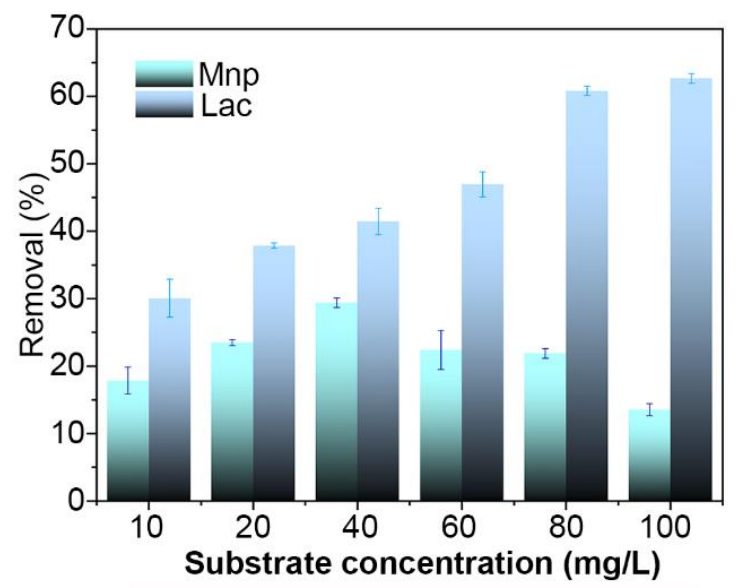

Fig. 3. Effect of the substrate concentration on the degradation of alkali lignins via Mnp and Lac

\section{Effect of the Ligninolytic Enzyme Activity on the Degradation of Alkali Lignins via Manganese Peroxidase and Laccase}

To study the effect of different ligninolytic enzyme activity levels on the removal of alkali lignins, a degradation system with different enzyme activity levels was constructed. An increase in Mnp enzyme activity led to an increased alkali lignin removal. The removal was $18.4 \%$ with an enzyme activity of $3.6 \mathrm{U} / \mathrm{mL}$, which was significantly higher than the removal of other enzyme activity levels in a Mnp degradation system. However, there was no significant difference in the removal between an enzyme activity of 0.4 or $2.0 \mathrm{U} / \mathrm{mL}$. At the same time, the removal of alkali lignins was up-regulated (resulting in a significant difference) with an increase in enzyme activity in a Lac degradation system. Furthermore, the control group (containing deactivated lignin degrading enzymes) still had the ability to remove alkali lignins, but the removal of the degradation system with enzyme activity was significantly higher than that the removal of the control group (as shown in Table 2). This suggested that Phanerochaete chrysosporium and Pleurotus ostreatus strains both secreted flocculating polysaccharides and that the two white rot fungi may secrete enzymes that can flocculate or degrade alkali lignins. 
Table 2. Effects of Different Ligninolytic Enzyme Activity Levels on the Alkali Lignin Removal

\begin{tabular}{|c|c|c|c|c|c|c|}
\hline \multirow{2}{*}{$\begin{array}{c}\text { Degradation } \\
\text { System }\end{array}$} & \multicolumn{7}{|c|}{ Enzyme Activity (U/mL) } \\
\cline { 2 - 7 } & Control & 0.4 & 1.2 & 2 & 2.8 & 3.6 \\
\hline $\begin{array}{c}\text { The Mnp } \\
\text { degradation } \\
\text { system }\end{array}$ & $\begin{array}{c}2.49 \pm \\
0.94^{\mathrm{d}}\end{array}$ & $\begin{array}{c}7.89 \pm \\
1.81^{\mathrm{c}}\end{array}$ & $\begin{array}{c}8.99 \pm \\
1.65^{\mathrm{c}}\end{array}$ & $\begin{array}{c}10.30 \pm \\
1.09^{\mathrm{c}}\end{array}$ & $\begin{array}{c}15.28 \pm \\
1.90^{\mathrm{b}}\end{array}$ & $\begin{array}{c}18.40 \pm \\
1.51^{\mathrm{a}}\end{array}$ \\
\hline $\begin{array}{c}\text { The Lac } \\
\text { degradation } \\
\text { system }\end{array}$ & $\begin{array}{c}8.25 \pm \\
1.12^{f}\end{array}$ & $\begin{array}{c}15.81 \pm \\
2.27^{\mathrm{e}}\end{array}$ & $\begin{array}{c}20.02 \pm \\
1.53^{\mathrm{d}}\end{array}$ & $\begin{array}{c}26.99 \pm \\
2.30^{\mathrm{c}}\end{array}$ & $\begin{array}{c}34.08 \pm \\
2.49^{\mathrm{b}}\end{array}$ & $\begin{array}{c}38.11 \pm \\
1.39^{\mathrm{a}}\end{array}$ \\
\hline $\begin{array}{l}\text { Note: Values in a row with different superscript letters (a, b, c, d, e, or f) differ at a } p- \\
\text { value less than 0.05, while values with the same letter were not significant. }\end{array}$ \\
\hline
\end{tabular}

\section{Analysis of the Alkali Lignin Removal via Two Lignin Degrading Enzymes}

The Mnp and Lac degradation reaction liquid was prepared for ultraviolet spectral analysis. The results showed that the same trend was observed in the separate Mnp and Lac lignin degradation systems. The absorption peak of alkali lignins at $280 \mathrm{~nm}$ did not shift, and the ultraviolet absorption in the wavelength range $200 \mathrm{~nm}$ to $300 \mathrm{~nm}$ did not increase. However, there was a slight change in the wavelength range of $250 \mathrm{~nm}$ to $280 \mathrm{~nm}$ in the two degradation systems, which indicated that precipitation played a major role in the removal of alkali lignins from the solution phase (as shown in Fig. 4A). The GC-MS analysis results showed that degradation also contributed to the removal of alkali lignins. The degradation primarily produced organic acids, esters, and aromatic substances (as shown in Fig. 4B, Fig. 4C, Table 3, and Table 4).

\section{Discussion}

In this study, different degradation systems were constructed, and spectral analysis and GC-MS were performed in the reaction liquid from these lignin degradation enzyme systems. The authors found that white rot fungi removed lignin primarily via precipitation, while enzymolysis was a secondary effect.

Since alkali lignins are the primary cause of the formation of black liquor, the change in absorbance caused by color can reflect the change in the concentration of alkali lignins, and then the degradation rate can be obtained (Prasanna et al. 2007). Therefore, the alkali lignin degradation rate was determined by measuring the change in absorbance at a wavelength of $280 \mathrm{~nm}$ before and after the alkali lignin degradation system reaction, and the standard curve was drawn (Baldrian and Šnajdr 2006). In addition, the infrared spectrum analysis results showed that alkali lignins had hydroxyphenyl, guaiacyl, and other extensional vibrations, verifying that the alkali lignins contained a large number of benzene ring structures.

The precipitation of alkali-lignins in the constructed degradation systems may be due to the fact that purified alkali-lignins are a type of macromolecule organic compound with a three-dimensional network structure and poor solubility, which can be used as an anion flocculant for proteins in fermentation broth (Qiao et al. 2006). In addition, fermentation broths containing Phanerochaete chrysosporium and Pleurotus ostreatus strains were used to construct both lignin-degrading enzyme degradation systems, which may contain flocculating proteins and polysaccharide. 

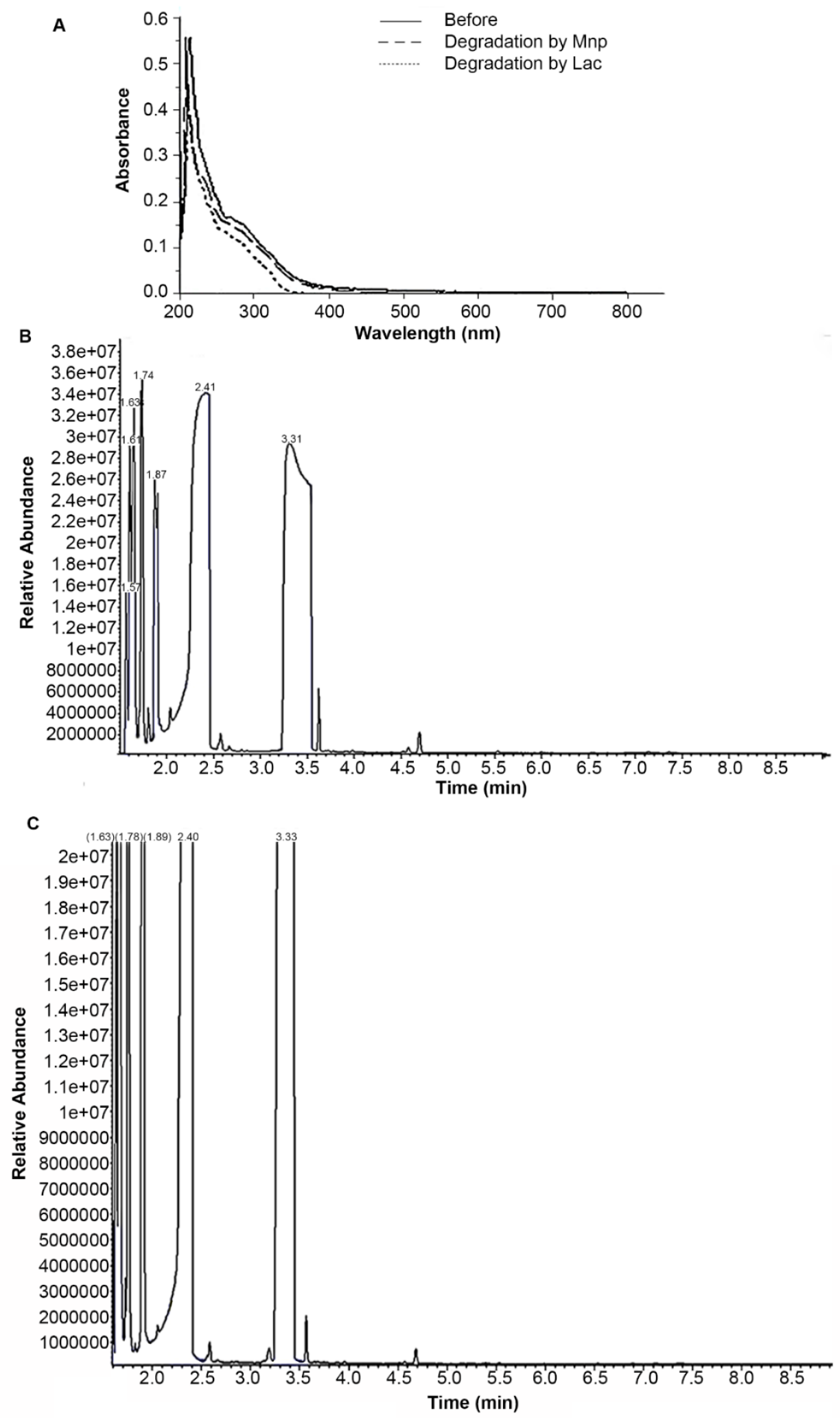

Fig. 4. Analysis of the alkali lignin removal via two lignin degrading enzymes: (A) UV-Vis spectra of the alkali lignins biodegraded via a Mnp or Lac reaction system; (B) GC-MS chromatogram of a sample from the alkali lignin biodegraded via a Mnp reaction system; (C) GC-MS chromatogram of a sample from the alkali lignin biodegraded via a Lac reaction system 
Table 3. Products of the Degradation of Alkali Lignins in a Mnp Degradation System

\begin{tabular}{|c|c|c|c|c|c|}
\hline $\begin{array}{c}\text { Retention } \\
\text { Time (min) }\end{array}$ & $\begin{array}{c}\text { Structural } \\
\text { Formula }\end{array}$ & Name & $\begin{array}{c}\text { Retention } \\
\text { Time (min) }\end{array}$ & $\begin{array}{c}\text { Structural } \\
\text { Formula }\end{array}$ & Name \\
\hline 1.827 & & $\begin{array}{c}2,5- \\
\text { Dichloropyridine }\end{array}$ & 3.982 & & $\begin{array}{l}\text { Ethanedioic } \\
\text { acid }\end{array}$ \\
\hline 2.460 & & $\begin{array}{c}2-(\mathrm{N}- \\
\text { phenethyl)- } \\
\text { ethylamino-4- } \\
\text { methyl } \\
\text { pentenoate }\end{array}$ & 5.536 & & $\begin{array}{c}\text { 2-(a- } \\
\text { naphthyl)-3- } \\
\text { allyl -4- } \\
\text { Mercaptoimid } \\
\text { azole }\end{array}$ \\
\hline 2.710 & & acetic acid & 12.825 & & glycerol \\
\hline 3.391 & & $\begin{array}{l}\mathrm{N} \text {-methyl-N- } \\
\text { ethylaniline }\end{array}$ & 13.821 & & $\begin{array}{l}\text { P-(2-phenyl) - } \\
\text { thiazolidinyl - } \\
\text { 3-methyl-p- } \\
\text { chlorobenzothi } \\
\text { ophene }\end{array}$ \\
\hline 3.728 & & $\begin{array}{l}\text { 4- phenyl -2- } \\
\text { butanol }\end{array}$ & 38.028 & & $\begin{array}{l}\text { Diisohexyl } \\
\text { phthalate }\end{array}$ \\
\hline 1.284 & & $\begin{array}{l}\text { 3- methylamino- } \\
\text { phenyl } \\
\text { isobutyrate }\end{array}$ & 9.280 & & $\begin{array}{c}\text { 4,4-dimethyl- } \\
\text { 4-(4- } \\
\text { hydroxyphenyl } \\
\text { )-2-butanone }\end{array}$ \\
\hline 2.671 & & propanoic acid & 18.806 & & $\begin{array}{c}2 ', 4^{\prime}- \\
\text { dihydroxy-3- } \\
(p- \\
\text { hydroxyphenyl } \\
\text { )- } \\
\text { propiophenon } \\
\text { e } \\
\end{array}$ \\
\hline 3.183 & & $\begin{array}{c}3,5- \\
\text { dimethylphenol }\end{array}$ & 21.891 & & $\begin{array}{c}2,4- \\
\text { dihydroxy- } \\
\text { benzoic acid }\end{array}$ \\
\hline 5.390 & & $\begin{array}{l}\text { Ethyl } \\
\text { alcohol }\end{array}$ & 44.492 & & $\begin{array}{l}\text { 4- formyl - } \\
\text { dimethyl } \\
\text { phthalate }\end{array}$ \\
\hline
\end{tabular}




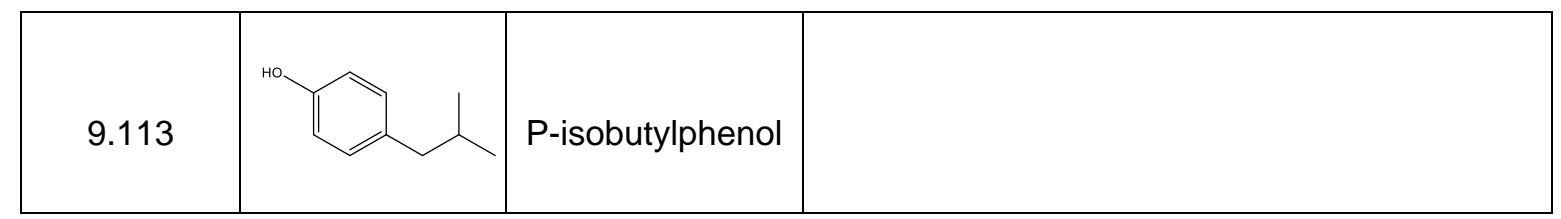

Table 4. Products of the Degradation of Alkali Lignins in a Lac Degradation System

\begin{tabular}{|c|c|c|c|c|c|}
\hline $\begin{array}{l}\text { Retention } \\
\text { Time (min) }\end{array}$ & $\begin{array}{c}\text { Structural } \\
\text { Formula }\end{array}$ & Name & $\begin{array}{l}\text { Retention } \\
\text { Time } \\
\text { (min) }\end{array}$ & $\begin{array}{l}\text { Structural } \\
\text { Formula }\end{array}$ & Name \\
\hline 1.284 & & $\begin{array}{c}\text { 3- } \\
\text { methylamino- } \\
\text { phenyl } \\
\text { isobutyrate }\end{array}$ & 9.280 & & $\begin{array}{l}\text { 4,4-dimethyl-4-(4- } \\
\text { hydroxyphenyl)-2- } \\
\text { butanone }\end{array}$ \\
\hline 2.671 & & propanoic acid & 18.806 & & $\begin{array}{c}\text { 2',4'-dihydroxy-3- } \\
\text { (p-hydroxyphenyl) } \\
\text { propiophenone }\end{array}$ \\
\hline 3.183 & & $\begin{array}{c}3,5- \\
\text { dimethylpheno } \\
\mid\end{array}$ & 21.891 & & $\begin{array}{l}\text { 2,4-dihydroxy- } \\
\text { benzoic acid }\end{array}$ \\
\hline 5.390 & & $\begin{array}{l}\text { Ethyl } \\
\text { alcohol }\end{array}$ & 44.492 & & $\begin{array}{l}\text { 4-formyl-dimethyl } \\
\text { phthalate }\end{array}$ \\
\hline 9.113 & & $\begin{array}{c}p- \\
\text { isobutylphenol }\end{array}$ & & & \\
\hline
\end{tabular}

Mnp and Lac are acidic proteins, which may be electrically neutralized with alkali lignins to produce floccule precipitation (Novotný et al. 2004). A previous study by Liu et al. (2014) showed that the removal mechanism of a Mnp and Lac degradation systems in terms of alkali lignins were flocculation, adsorption, and degradation. In order to study the primary mechanism of the reaction in the two systems, a low-concentration alkali wood $(10 \mathrm{mg} / \mathrm{L})$ degradation system with a weak flocculation phenomenon was selected for the experiment. The authors found that the enzyme activity of Mnp had no significant effect on the removal of alkali lignins. This may result from the fact that the Phanerochaete chrysosporium fermentation broth contained other proteins or polysaccharides, which can remove alkali lignins. Mnp may be only one of the secretions that is able to remove alkali lignins, and it is not a decisive factor for the removal of alkali lignins or in the range of enzyme activity from 0 to $3.6 \mathrm{U} / \mathrm{mL}$. Therefore, there was no significant difference in the removal of each degradation system with a Mnp enzyme activity of 0.4 to $2.0 \mathrm{U} / \mathrm{mL}$. However, Lac or other proteins secreted by Pleurotus ostreatus played a decisive role in the removal of alkaloids, and hence there were significant differences in the removal of the 
different Lac degradation systems. In addition, the removal of the Lac degradation systems were higher than the removal of the Mnp degradation systems, indicating that Pleurotus ostreatus strains secreted more flocculating substances than Phanerochaete chrysosporium strains. This may be caused by the mycelium development of Pleurotus ostreatus strains secreting more polysaccharide substances (Wesenberg et al. 2003). The control group without any lignin-degrading enzyme activity still had some ability to remove alkaloids, possibly because Phanerochaete chrysosporium and Pleurotus ostreatus secreted flocculating polysaccharides. However, the removal of the degradation systems with enzyme activity were significantly higher than the removal of the degradation system without enzyme activity, which indicated that both white rot fungi strains may secrete enzymes that flocculate or degrade alkali lignins. The flocculants produced by the Phanerochaete chrysosporium and Pleurotus ostreatus strains may contain both proteins and polysaccharides (Galliano et al. 1991).

In summary, white rot fungi could effectively remove alkali lignin, in which precipitation played a major role, followed by enzymolysis. The products of enzymolysis were mainly organic acids, esters, and aromatic substances. However, whether the purified alkali lignins had a partial benzene ring structure fracture or mineralization in the Mnp and Lac degradation systems requires further study. This study provided new ideas for effective lignin degradation, which may be helpful to solve the problem of recycling paper and pulp industry effluents in the future.

\section{CONCLUSIONS}

1. In the process of removing alkali lignin by white rot fungi, precipitation played a major role, followed by enzymolysis.

2. Precipitation in the Lac degradation system occurred earlier, as well as being more obvious, than the precipitation in the Mnp degradation system. For the Mnp degradation system, the maximum removal was $29.4 \%$ at a concentration of $40 \mathrm{mg} / \mathrm{L}$, which decreased as the concentration of alkali lignin increased (decreased to $13.54 \%$ at a concentration of $100 \mathrm{mg} / \mathrm{L}$ ). For the Lac degradation system, the removal of alkali lignins was up-regulated in a concentration-dependent manner. It reached up to $62.7 \%$ at a concentration of $100 \mathrm{mg} / \mathrm{L}$.

3. An increase in Mnp enzyme activity led to an increased alkali lignin removal. The removal was $18.4 \%$ with an enzyme activity of $3.6 \mathrm{U} / \mathrm{mL}$, which was significantly higher than the removal of other enzyme activity levels in a Mnp degradation system. Similarly, the removal of alkali lignins was up-regulated with an increase in enzyme activity in a Lac degradation system.

4. The group without lignin degrading enzymes still had the ability to remove alkali lignins, but the removal was significantly lower than that of the degradation system with enzyme activity. 


\section{ACKNOWLEDGMENTS}

This research was supported by a grant from the China Postdoctoral Science Foundation (2020M673112), the Wenzhou Science and Technology Bureau (Grant No. S2020005, W20170010), the National Natural Science Foundation of China (Grant No. 51808086), the Special project of basic research and frontier exploration in Chongqing (Grant No. cstc2018jcyjAX0078) and Provincial and Ministerial Co-constructive of Collaborative Innovation Center for Municipal Solid Waste Comprehensive Utilization (Grant No. shljzyh2021-23).

\section{REFERENCES CITED}

Baldrian, P., and Šnajdr, J. (2006). "Production of ligninolytic enzymes by litterdecomposing fungi and their ability to decolorize synthetic dyes," Enzyme and Microbial Technology 39(5), 1023-1029. DOI: 10.1016/j.enzmictec.2006.02.011

Cheng, F., and Brewer, C. E. (2017). "Producing jet fuel from biomass lignin: Potential pathways to alkyl-benzenes and cycloalkanes," Renewable and Sustainable Energy Reviews 72, 673-722. DOI: 10.1016/j.rser.2017.01.030

De Koker, T. H., Zhao, J., Cullen, D., and Janse, B. J. H. (1998). "Biochemical and molecular characterization of South African strains of Phanerochaete chrysosporium," Mycological Research 102(1), 88-92. DOI: 10.1017/S095375629700453X

Galliano, H., Gas, G., Series, J. L., and Boudet, A. M. (1991). 'Lignin degradation by Rigidoporus lignosus involves synergistic action of two oxidizing enzymes: Mn peroxidase and laccase," Enzyme and Microbial Technology 13(6), 478-482. DOI: 10.1016/0141-0229(91)90005-U

Ghiaci, M., Molaie, F., Sedaghat, M. E., and Dorostkar, N. (2010). "Metalloporphyrin covalently bound to silica. Preparation, characterization and catalytic activity in oxidation of ethyl benzene," Catalysis Communications 11(8), 694-699. DOI: 10.1016/j.catcom.2010.01.023

Hofrichter, M., Lundell, T., and Hatakka, A. (2001). "Conversion of milled pine wood by manganese peroxidase from Phlebia radiata," 67(10), 4588-4593. DOI:

10.1128/AEM.67.10.4588-4593.2001

Ihssen, J., Jankowska, D., Ramsauer, T., Reiss, R., Luchsinger, R., Wiesli, L., Schubert, M., Thöny-Meyer, L., and Faccio, G. (2017). "Engineered Bacillus pumilus laccaselike multi-copper oxidase for enhanced oxidation of the lignin model compound guaiacol," Protein Engineering, Design and Selection 30(6), 449-453. DOI: 10.1093/protein/gzx026

Jordaan, M., and Laurens, J. B. (2015). "Diagnosis of Helicobacter pylori infection with the ${ }^{13} \mathrm{C}$-urea breath test by means of GC-MS analysis," 31(2), 329-335. DOI: 10.1002/jssc. 200700385

Jose, S., Mishra, L., Basu, G., and Samanta, A. K. (2017). "Study on reuse of coconut fiber chemical retting bath. Part II---Recovery and characterization of lignin," Journal of Natural Fibers 14(4), 1-9. DOI: 10.1080/15440478.2016.1212772

Liu, Y., Hu, T., Zeng, G., Zhao, X., Huang, D., Shen, Y., and Yin, L. (2014). "Mechanism of adsorption and degradation of alkali lignin in aqueous solution by Penicillium simplicissimum," Chinese Journal of Environmental Engineering 8(3), 
1007-1013.

Novotný, C., Svobodová, K., Erbanová, P., Cajthaml, T., Kasinath, A., Lang, E., and Šašek, V. (2004). "Ligninolytic fungi in bioremediation: Extracellular enzyme production and degradation rate," Soil Biology and Biochemistry 36(10), 1545-1551. DOI: $10.1016 /$ j.soilbio.2004.07.019

Pezzella, C., Autore, F., Giardina, P., Piscitelli, A., Sannia, G., and Faraco, V. (2008). "The Pleurotus ostreatus laccase multi-gene family: Isolation and heterologous expression of new family members," Current Genetics 55, 45-57. DOI: 10.1007/s00294-008-0221-y

Prasanna, P., Ramesh, S., Bolton, T. S., Shigetoshi, O., and Francis, R. C. (2007). "Estimation of hardwood lignin concentrations by UV spectroscopy and chlorine demethylation," BioResources 2(3), 459-471. DOI: 10.15376/biores.2.3.459-471

Qiao, J., Ping, T., Binghua, Y., and Baozhong, D. (2006). "A study on isolation and characterization of biodegrading bacteria for crystal violet dye," Techniques and Equipment for Environmental Pollution Control 7(2), 62-65.

Ryu, W. Y., Jang, M. Y., and Cho, M. H. (2003). "The selective visualization of lignin peroxidase, manganese peroxidase and laccase, produced by white rot fungi on solid media," Biotechnology and Bioprocess Engineering 8(2), 130-134. DOI: 10.1007/BF02940268

Saparrat, M. C. N., Mocchiutti, P., Liggieri, C. S., Aulicino, M. B., Caffini, N. O., Balatti, P. A., and Martínez, M. J. (2008). "Ligninolytic enzyme ability and potential biotechnology applications of the white-rot fungus Grammothele subargentea LPSC no. 436 strain," Process Biochemistry 43(4), 368-375. DOI: 10.1016/j.procbio.2007.12.016

Soloman, P. A., Basha, C. A., Velan, M., and Balasubramanian, N. (2009). "Electrochemical degradation of pulp and paper industry waste-water," Journal of Chemical Technology \& Biotechnology 84, 1303-1313. DOI: 10.1002/jctb.2176

Tian, Z., Zong, L., Niu, R., Wang, X., Li, Y., and Ai, S. (2015). "Recovery and characterization of lignin from alkaline straw pulping black liquor: As feedstock for bio-oil research," Journal of Applied Polymer Science 132(25), 1-9. DOI: 10.1002/app.42057

Wang, L., Shen, S., Yang, S., and Shi, X. (2010). "Experimental investigation of pyrolysis process of corn straw," International Journal of Low-Carbon Technologies 5(4), 182-185. DOI: 10.1093/ijlct/ctq018

Wesenberg, D., Kyriakides, I., and Agathos, S. N. (2003). "White-rot fungi and their enzymes for the treatment of industrial dye effluents," 22(1-2), 161-187. DOI: 10.1016/j.biotechadv.2003.08.011

Ye, L., Spiteller, D., Ullrich, R., Boland, W., Nüske, J., and Diekert, G. (2010). "Fluoride-dependent conversion of organic compounds mediated by manganese peroxidases in the absence of $\mathrm{Mn}^{2+}$ ions biochemistry," Biochemistry 49(34), 72647271. DOI: $10.1021 / \mathrm{bi100831w}$ 
Yoshikata, T., Suzuki, K., Kamimura, N., Namiki, M., Hishiyama, S., Araki, T., Kasai, D., Otsuka, Y., Nakamura, M., Fukuda, M., et al. (2014). "Three-component Odemethylase system essential for catabolism of a lignin-derived biphenyl compound in Sphingobium sp. strain SYK-6," Applied and Environmental Microbiology 80(23), 7142-7153. DOI: 10.1128/AEM.02236-14

Article submitted: October 21, 2020; Peer review completed: January 16, 2021; Revised version received: April 1, 2021; Further revised version received and accepted: June 3, 2021; Published: June 15, 2021.

DOI: 10.15376/biores.16.3.5494-5507 